\title{
Impact of grazing management on hibernating caterpillars of the butterfly Melitaea cinxia in calcareous grasslands
}

\author{
C. G. E. van Noordwijk • Daphne E. Flierman • \\ Eva Remke • Michiel F. WallisDeVries • \\ Matty P. Berg
}

Received: 5 September 2011/Accepted: 9 March 2012/Published online: 29 March 2012

(C) The Author(s) 2012. This article is published with open access at Springerlink.com

\begin{abstract}
Semi-natural grasslands are increasingly grazed by large herbivores for nature conservation purposes. For many insects such grazing is essential for the conservation of their habitat, but at the same time, populations decrease at high grazing intensity. We hypothesised that grazing management may cause increased butterfly mortality, especially for life-stages with low mobility, such as
\end{abstract}

Electronic supplementary material The online version of this article (doi:10.1007/s10841-012-9478-z) contains supplementary material, which is available to authorized users.

C. G. E. van Noordwijk ( $₫)$ · D. E. Flierman · E. Remke Bargerveen Foundation, Toernooiveld 1, 6525 ED Nijmegen, The Netherlands

e-mail: t.vannoordwijk@science.ru.nl

D. E. Flierman

e-mail: deflierman@hotmail.com

E. Remke

e-mail: e.remke@science.ru.nl

C. G. E. van Noordwijk - E. Remke

Department of Animal Ecology and Ecophysiology, Institute of Water and Wetland Research, Radboud University Nijmegen, P.O. Box 9010, 6500 GL Nijmegen, The Netherlands

M. F. WallisDeVries

De Vlinderstichting-Dutch Butterfly Conservation,

P.O. Box 506, 6700 AM Wageningen, The Netherlands

e-mail: michiel.wallisdevries@ vlinderstichting.nl

M. F. WallisDeVries

Laboratory of Entomology, Wageningen University,

P.O. Box 8031, 6700 EH Wageningen, The Netherlands

\section{P. Berg}

Department of Ecological Science, Section Animal Ecology,

VU University Amsterdam, De Boelelaan 1085, 1081 HV

Amsterdam, The Netherlands

e-mail: m.p.berg@vu.nl hibernating caterpillars. To test this, we measured the effect of sheep grazing on overwinter larval survival. We used the Glanville fritillary (Melitaea cinxia), which has gregarious caterpillars hibernating in silk nests, as a model species. Caterpillar nests were monitored throughout the hibernating period in calcareous grassland reserves with low and high intensity sheep grazing and in an ungrazed control treatment. After grazing, $64 \%$ of the nests at the high intensity grazing treatment were damaged or missing, compared to 8 and $12 \%$ at the ungrazed and low intensity grazing treatment, respectively. Nest volume and caterpillar survival were $50 \%$ lower at the high intensity grazing treatment compared to both ungrazed and low intensity grazing treatments. Nest damage and increased mortality were mainly caused by incidental ingestion of the caterpillars by the sheep. It is likely that grazing similarly affects other invertebrates, depending on their location within the vegetation and their ability to actively avoid herbivores. This implies that the impact of grazing strongly depends on the timing of this management in relation to the phenology of the species. A greater focus on immature and inactive life-stages in conservation policy in general and particularly in action plans for endangered species is required to effectively preserve invertebrate diversity.

Keywords Life-history traits - Invertebrate biodiversity . Butterfly conservation · Lepidoptera $\cdot$ Herbivore predation . Incidental omnivory

\section{Introduction}

Nutrient-poor, semi-natural grasslands harbour a large part of the biodiversity in temperate climates, especially for plants and insects (Stevens et al. 2004; WallisDeVries et al. 
2002). Biodiversity in these grasslands depends strongly on management, such as grazing or cutting (Baldock et al. 1996; Morris 2000; Ostermann 1998; Willems 2001). Management is essential to prevent encroachment of tall grasses, shrubs and trees and it facilitates the development of a heterogeneous vegetation structure that provides a suitable habitat for numerous plant and animal species (Morris 2000; Morris et al. 1990; Willems 2001). Historically, management in most semi-natural grasslands in Western Europe consisted of low-intensity farming practices (Ostermann 1998; Poschlod and WallisDeVries 2002). Over the past century, agricultural intensification and the introduction of artificial fertilizers have led to abandonment of these farming practices and conversion of semi-natural grasslands to arable land and high intensity agricultural grassland (Baldock et al. 1996). This resulted in a strong decline in species richness (Stevens et al. 2004; van Swaay et al. 2010; WallisDeVries et al. 2002). In addition, absence of management in remaining sites has led to severe grass, shrub and tree encroachment, causing plant and insect species richness to decline even further (Dover et al. 2011; WallisDeVries et al. 2002; Willems 2001). In many sites the problems caused by fragmentation and abandonment were further amplified by eutrophication from both adjacent agricultural areas (run-off) and airborne nitrogen pollution (Bobbink and Willems 1993; Willems 2001). These land use changes resulting from abandonment of traditional agricultural practices across Europe are believed to be one of the largest threats to European butterflies (van Swaay et al. 2010).

To counter the negative effects of abandonment on grassland biodiversity, remaining semi-natural grasslands are now increasingly managed for nature conservation purposes (Ostermann 1998) or included in agri-environment schemes (WallisDeVries et al., 2007; Konvicka et al. 2008). Conservation management of semi-natural grasslands usually consists of mowing or grazing with large herbivores. These new management practices often lead to conflicting interests, because various taxonomic groups differ in their response to particular management measures (Kruess and Tscharntke 2002a; Oertli et al. 2005; Vessby et al. 2002). The reason for this conflict is that current management, although necessary for the conservation of semi-natural habitats, can be detrimental to part of the characteristic species of semi-natural grasslands (Carvell 2002; Humbert et al. 2010; Morris 2000; Morris et al. 1990). Insects in general (Bourn and Thomas 2002; Kruess and Tscharntke 2002a; Mortimer et al. 1998; Samways 1994) and especially butterflies (Franzén and Ranius 2004; Schtickzelle et al. 2007; Konvicka et al. 2008) have proven to be very sensitive to some management measures. This demonstrates the need for appropriate action plans in which specific attention is paid to the needs of grassland butterflies.
There is growing evidence from nature conservation research that the impact of management practices on species strongly depends on their life-cycle and associated traits (van Kleef et al. 2006; van Noordwijk et al. 2012; Verberk et al. 2008). To what extent a species can escape temporarily unfavourable conditions is determined by its mobility (Dennis et al. 1998; Siepel 1995; van Kleef et al. 2006), while its microhabitat (e.g. height within the meadow vegetation strata) determines to what extent species are affected by grazing or mowing management (Humbert et al. 2009). In species with distinct periods of larval and adult activity the impact of a management measure also strongly depends on management timing in relation to the phenology of the species (Konvicka et al. 2008; Humbert et al. 2009; Morris 1973; Morris et al. 1990). To estimate the impact of management practices in relation to species traits, it is essential to incorporate the requirements of all life-stages and to evaluate which life-stages will actually be affected (i.e. will be present during the management period). It is widely acknowledged that the requirements of eggs and larval stages are often more demanding than those of the adult stages (Bourn and Thomas 2002; Fartmann and Hermann 2006). Eggs and larval stages of most insects are also considerably less mobile than adult stages (Bourn and Thomas 2002), making them more vulnerable, as they cannot escape temporarily unfavourable conditions (Dennis et al. 1998).

In practice, few conservation management plans, including European agri-environment schemes, explicitly incorporate the importance of species life-history traits and the particular vulnerability of immature stages (see Aviron et al. 2010; Pywell et al. 2011). Scientific studies investigating negative effects of conservation management on butterflies have predominantly addressed larval habitat requirements indirectly, by focussing on changes in adult abundance and relating these to changes in vegetation structure or food availability (Kruess and Tscharntke 2002b; Poyry et al. 2006; Schtickzelle et al. 2007; WallisDeVries et al. 2007). This focus may result in an incomplete assessment of larval habitat quality and bias management towards the needs of adult life stages. Recommendations resulting from these studies often emphasize to decrease management intensity during the adult flight season and increase management efforts in autumn and winter when species are hibernating as immature stages (Ellis 2003; Morris 1973; Oates 1995; Schtickzelle et al. 2007). From a life-history trait perspective these immature and inactive life-stages may, however, be even more vulnerable to mowing or grazing management than their adult counterparts. Actual data on the impact of management on the larval stages are therefore urgently required to improve butterfly conservation (Fartmann and Hermann 2006; Thomas et al. 2011). 
The aim of our study was to quantify the direct effects of autumn grazing on hibernating caterpillars and to shed light on the underlying mechanisms. The ensuing information could prove essential to arrive at more effective management schemes for conservation. We hypothesised that grazing management may cause increased mortality in hibernating caterpillars. Hibernating caterpillars were expected to be unable to escape grazing animals and may therefore be trampled or ingested. We expected that caterpillar mortality would increase with increasing grazing intensity as this would lead to increased encounter rates. These hypotheses were tested with a field experiment using the Glanville fritillary (Melitaea cinxia) in calcareous grasslands grazed by sheep as a model system. The Glanville fritillary was chosen as a model species because it has gregarious caterpillars hibernating in silk nests that are more easily retraced than individual caterpillars (Hanski 1999; WallisDeVries 2006).

\section{Methods}

\section{Site description}

The experiment was conducted on two calcareous grasslands differing in sheep grazing intensity, near the city of Maastricht; Thier de Lanaye (Belgium) and Bemelerberg (the Netherlands). Thier de Lanaye $\left(50^{\circ} 46^{\prime}\right.$ $41^{\prime \prime} \mathrm{N}, 5^{\circ} 40^{\prime} 45^{\prime \prime} \mathrm{E}$, altitude $80 \mathrm{~m}$ ) is situated on the west-bank of the Meuse valley and consists of grassland (4 ha) surrounded by deciduous woods. The calcareous grassland is divided into five sections by permanent fencing, which are grazed separately in one or more rounds between April and October each year. Our experiment was conducted in one of these sections (size 0.5 ha, slope $23^{\circ}$, exposition south-east), which is only grazed in autumn at low stocking densities. Bemelerberg $\left(50^{\circ} 51^{\prime} 03^{\prime \prime} \mathrm{N}, 5^{\circ} 46^{\prime} 09^{\prime \prime} \mathrm{E}\right.$, altitude $\left.90 \mathrm{~m}\right)$ is located about $10 \mathrm{~km}$ northeast of Thier de Lanaye on the northbank of a dry valley. This site consists of a number of calcareous grasslands interspersed with deciduous woodland and agricultural fields. The grassland section used in this experiment (size 4 ha, slope $20^{\circ}$, exposition south-east) is grazed at high stocking densities in autumn with additional spring grazing (high stocking densities) and winter grazing (low stocking densities) in some parts. Both study sites are grazed with a local, traditional sheep breed (Mergelland).

\section{Study species}

Field studies on larval survival are hampered by the difficulty to monitor individual caterpillars in the field. This difficulty was overcome here by using a species with gregarious caterpillars, the Glanville fritillary (Melitaea cinxia), as a model species. Melitaea cinxia was primarily chosen because of its gregariously hibernating caterpillars, which make it easier to study the caterpillars throughout the season in the field. We expected that the mechanistic understanding provided by this type of research would enable us to evaluate to what extent the results can be extrapolated to other non-gregarious species. In any case this research would provide valuable information for other gregariously hibernating butterfly species, including the highly threatened Marsh fritillary (Euphydryas aurinia), which is a European Habitats Directive species (Smee et al. 2011).

Melitaea cinxia is a characteristic butterfly of calcareous, to slightly acidic dry grasslands. They are especially found in sites with substantial variation in vegetation structure and a high abundance of flowering plants (Bink 1992; Kuussaari 1998; WallisDeVries 2006). The species has a large Eurasian distribution (Bink 1992), its northern limit coincides with a July isotherm of $16.5-17.0{ }^{\circ} \mathrm{C}$. The flight period of M. cinxia peaks between mid-May and midJune (Bink 1992). Oviposition typically occurs in clusters of 100-200 eggs on the underside of the leaves of its host plant, predominantly ribwort plantain (Plantago lanceola$t a)$ in northwestern Europe. The caterpillars hibernate gregariously in a densely woven silk nest in tufts of grass (WallisDeVries 2006), typically $5-10 \mathrm{~cm}$ above the ground (personal observation). The larvae remain gregarious in spring until the final instar. The population of $M$. cinxia at Thier de Lanaye was reintroduced in 1997 (Goffart et al. 2001). The population at Bemelerberg was established in 2007 from an introduction of fourteen larval nests from Thier de Lanaye. In the first year after introduction part of the grassland containing most caterpillar nests was fenced off during grazing in autumn.

Nest selection and experimental design

Melitaea cinxia nests were searched in both study sites on three occasions between 15th July and 25th August 2009 (Supplementary Fig. $1 \& 2$ ). Each nest was marked by placing a $50 \mathrm{~cm}$ long PVC pole next to it. Nest locations were mapped (accuracy $10 \mathrm{~cm}$ ) using a grid of fixed poles with known GPS coordinates and ArcGIS 9.1 software. In total 120 nests were found at the high intensity grazing site (Bemelerberg) and 41 at the low intensity grazing site (Thier de Lanaye). The volume of each nest was calculated from length $\times$ height $x$ width measurements that were taken using a vernier calliper. At the low intensity grazing site we selected the 25 largest nests for subsequent monitoring. At the high intensity grazing site the area containing the highest nest density was split in two and one half was 
fenced off using flexible electric fencing to form an ungrazed control treatment. These grazed and ungrazed plots at the high intensity grazing site were located next to each other and were very similar in slope, exposition and vegetation composition. Pairs of equally sized nests were selected for further monitoring in these two treatments, working from the largest nests down until we had selected 25 nests per treatment. Around each selected nest in both study sites we conducted an extensive search to detect and remove any other nests in the immediate vicinity. Nests that were less than $50 \mathrm{~cm}$ away from the selected nests were excluded and later physically removed from the experimental plots to enable accurate caterpillar counts per nest in spring. The final set-up consisted of three grazing treatments; low intensity grazing (Thier de Lanaye, 25 caterpillar nests), high intensity grazing (Bemelerberg, 25 caterpillar nests) and no grazing (exclosure Bemelerberg, 24 caterpillar nests). The treatments were not replicated in different sites as we did not have access to multiple sites with similar management and a sufficiently large population of the study species. Therefore, this experiment does not allow us to make general statements on the effects of the studied grazing intensities on caterpillar survival. Nonetheless, as caterpillar nests were at least 1 meter apart and grazing effects generally occur on a much smaller spatial scale (Parsons and Dumont 2003; Prache et al. 1998), the individual nests can be viewed as full replicates of the impact of grazing under the given circumstances. As the circumstances at the ungrazed and high intensity grazing treatment were equal except for the grazing treatment (the exclosure was especially erected for this experiment and the two treatments were located adjacent to each other), any differences found can be attributed to the grazing regime. Therefore, this study gives valuable insight in the effects grazing can have on hibernating caterpillars. The second site, with a different grazing regime, gives some insight in the generality of the effects of grazing.

Grazing was conducted in the second half of September in both grazed treatments (Table 1). At the high intensity grazing treatment, this was followed by a second grazing round at lower stocking densities. Prior to grazing all poles were removed to avoid attraction of the sheep to the nests. Instead, nests were individually marked with plastic arrows that were secured to the ground with nails and were placed at a distance of $30-70 \mathrm{~cm}$ from the nest. The arrows pointed towards the nest and had the nest ID and distance marked on them to facilitate nest searching. A number of nests of different sizes that were not included in the experiment (20 nests at Bemelerberg and 5 nests at Thier de Lanaye), were used to test nest volume as a proxy for the number of caterpillars per nest. In August 2009 these nests were measured as described above and opened to count the caterpillars inside.
Nest monitoring

Nest volume, nest height and vegetation height at the nest location were measured for each nest before grazing started in September and after the first (October) and second (December) grazing round. Vegetation height at the nest location was also measured in March 2010. Nest volume was measured as described above. Nest height was defined as the height of the top of each nest above the ground and was measured with a ruler to the nearest $\mathrm{mm}$. The vegetation height at each nest location was measured by carefully lowering a drop disk (10 $\mathrm{cm}$ diameter, weighing $8 \mathrm{~g}$ ) directly above the nest. After every grazing round each single nest was visually inspected and photographed. Nests without any external signs of damage were classified as undamaged (Supplementary Figs. $3 \& 4$ ). Nests with small holes, signs of tear or signs of repair of the silken nest were classified as lightly damaged (Supplementary Fig. 5 \& 6). Nests were classified as heavily damaged (Supplementary Fig. $7 \& 8$ ) if part of the nest was absent or so heavily damaged that caterpillars had fallen out of the nest. If nests could not be retrieved they were classified as missing. In spring (early March 2010), the number of caterpillars per nest was counted. These counts were conducted on the first sunny days of the season when the caterpillars were usually basking on top of or next to their nests. At this stage, nests were opened to count all living caterpillars inside.

\section{Statistical analysis}

To establish whether there were any differences between the treatments prior to grazing we tested for differences in vegetation height (ANOVA) and nest volume ( $t$ tests). For a selection of nests $(n=25)$ we tested whether caterpillar density (number of caterpillars per nest volume) differed between the two study sites using a students $t$ test. Next, the relationship between the number of caterpillars and nest volume was explored with a Pearson correlation coefficient.

Changes in vegetation height over time were used as an objective measure of grazing intensity. Differences in vegetation height at each nest locations (within subject factor) over time and between treatments (between subject factor) were explored using a repeated measures ANOVA (nest locations were fixed and individually marked). A Greenhouse-Geisser correction was used to correct for violations of sphericity (Greenhouse and Geisser 1959). To establish whether the vegetation height declined evenly, or alternatively declined especially at patches with short or long swards (grazing preference of the sheep), we correlated vegetation decline during the first grazing round to the original vegetation height (Pearson correlation coefficient). 
Table 1 Observed grazing intensity during the experiment in autumn 2009

\begin{tabular}{lllll}
\hline Treatment & Number of sheep & Compartment size (ha) & Grazing period date (days) & Grazing intensity (sheep days ha $^{-1}$ ) \\
\hline No grazing & $5^{\mathrm{a}}$ & 0.15 & Sept 26 (1) & $<35$ \\
Low intensity grazing & 26 & 0.52 & Sept 17 to Sept 23 (6) & 300 \\
High intensity grazing & & & & 1353 \\
Round 1 & 114 & 1.23 & Sept 17 to Sept 27 (10) & 927 \\
Round 2 & 15 & 1.76 & Sept 29 to Nov 18 (50) & 426 \\
\hline
\end{tabular}

${ }^{a}$ A group of 5 sheep managed to enter the exclosure forming the ungrazed control treatment overnight. They were detected and removed within one day and the fence was improved afterwards

Differences in nest damage between treatments were explored with non-parametric statistics. Additionally, we tested whether nest damage occurred especially in nests that were situated low (more vulnerable to trampling) or high (more vulnerable to incidental ingestion) in the vegetation (ANOVA). We also explored the vegetation height at each individual nest location after grazing, in relation to the height of the nest prior to grazing. This gave an indication of ingestion of whole or partial caterpillar nests by the sheep during grazing.

We explored differences in nest volume and spring caterpillar counts between treatments using parametric statistics (ANOVA and $t$ test with Tukey post hoc tests). As the nest volume prior to grazing differed between the two study sites we used relative nest volume (percentage of the nest volume prior to grazing) and relative caterpillar count (number of caterpillars relative to the nest size prior to grazing).

To satisfy normal distribution conditions vegetation heights were natural logarithmic transformed and absolute and relative nest volumes were square root transformed. Where several pairwise tests were conducted together, critical $p$ values were Bonferroni corrected to account for the number of tests performed. All statistical tests were performed using SPSS for windows 16.0.1.

\section{Results}

Vegetation height

Vegetation height at the caterpillar nest locations did not differ between treatments prior to grazing (ANOVA, $\mathrm{F}_{2}$, $71=2.1, p=0.13)$. Vegetation height declined during the experiment in all treatments (Fig. 1, Repeated measures ANOVA, $\left.\mathrm{F}_{2,135}=117.3, p<0.001\right)$. The rate of decline increased with increasing grazing intensity (interaction time $\times$ treatment, $\left.\mathrm{F}_{4,135}=6.5, p<0.001\right)$. However, the percentage decline in vegetation height differed only between grazing treatments after the first grazing round (Kruskal-Wallis, Chi-square $=26.5, p<0.001$ ), not after the second (Kruskal-Wallis, Chi-square $=1.9, p=0.38$ ). The reduction in vegetation height during the first grazing round was strongly positively correlated to the vegetation height prior to grazing for each grazing treatment (Pearson Correlation, $r>0.6, n>23, p<0.001)$.

Nest survival and status

Overall nest survival was high, with all nests surviving until spring at the ungrazed treatment $(n=24), 96 \%$ nest survival at the low intensity grazing treatment $(n=25)$ and $88 \%$ nest survival at the high intensity grazing treatment $(n=25)$. In both grazed treatments one nest $(4 \%)$ went missing during the first grazing round. Two more

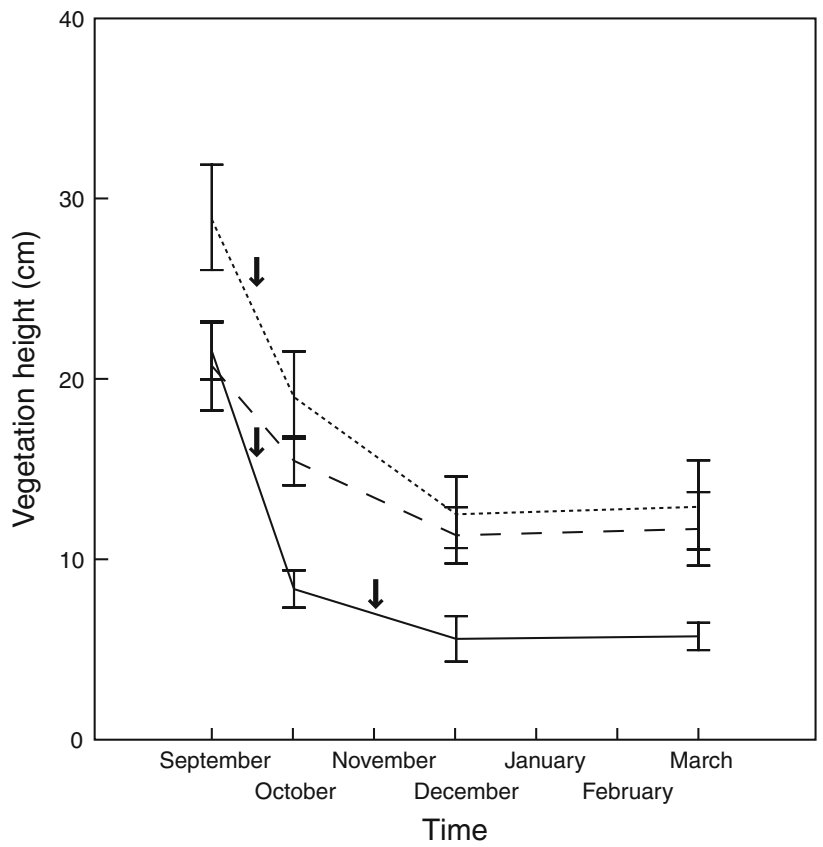

Fig. 1 Mean vegetation height at the caterpillar nest locations $( \pm 1$ $\mathrm{SE}$ ) prior to grazing (September), after the first grazing round (October), after the second grazing round (December) and after hibernation (March) for the high intensity grazing treatment (solid line), the low intensity grazing treatment (dotted line) and the ungrazed control treatment (dashed line). Grazing events are indicated with an arrow 
nests $(8 \%)$ went missing in the high intensity grazing treatment during the second grazing round. After the first grazing round $60 \%$ (15 nests) of the nests at the high intensity grazing treatment appeared damaged, compared to $8 \%$ ( 2 nests) at both the ungrazed and low intensity grazing treatments (Fig. 2). While nest status (i.e. number of nests per nest damage category) differed significantly between grazing treatments after the first grazing round (Kruskal-Wallis, Chi-square $=23.7, p<0.001$; Table 2), no differences were found after the second grazing round (Kruskal-Wallis, Chi-square $=2.5, p=0.28$ ).

Some of the damaged nests showed signs of trampling (nests lay near the ground and were flattened). In the high intensity grazing treatment three nests looked trampled after the first grazing round (20\% of all damaged nests in this treatment), with two more nests showing trampling signs after the second grazing round. In the low intensity grazing treatment one nest showed signs of trampling after grazing. Overall, nest damage was unrelated to the height of the nest prior to grazing (ANOVA, $F_{3}, 70=0.84$, $p=0.47$ ). However, there was a strong link between nest status and vegetation height after grazing. At damaged nests vegetation height had decreased more strongly than at undamaged nests ( $t$ test, $\mathrm{T}_{72}=-6.56, p<0.001$ ),
Table 2 Pairwise comparisons in nest status between treatments after the first grazing round (Bonferroni corrected critical $p=0.01$ )

\begin{tabular}{llll}
\hline Grazing treatment & Mann-Whitney $U$ & $Z$ & $p$ \\
\hline No grazing-low intensity & 288 & -0.457 & 0.647 \\
No grazing-high intensity & 126 & -4.062 & $<0.001$ \\
Low intensity-high intensity & 150 & -3.631 & $<0.001$ \\
\hline
\end{tabular}

indicating grazing activity. Exploration of the vegetation height at each individual nest location after grazing, in relation to the height of the nest measured prior to grazing gave proof of incidental ingestion of caterpillar nests as a cause of the nest damage. At damaged nest sites, vegetation height had on average been reduced to $1.2 \mathrm{~cm}( \pm 1.8 \mathrm{SE}$, $n=21$ ) below the nest height prior to grazing. In contrast, vegetation height at undamaged nest sites, was on average $7.9 \mathrm{~cm}( \pm 0.4 \mathrm{SE}, n=53)$ above the height of the nest prior to grazing (Fig. 3).

Nest size as a proxy for caterpillar count

Nest volume in August was strongly correlated to the number of caterpillars per nest (Fig. 4, Pearson correlation, $r=0.79, n=25, p<0.001)$. There was no difference in

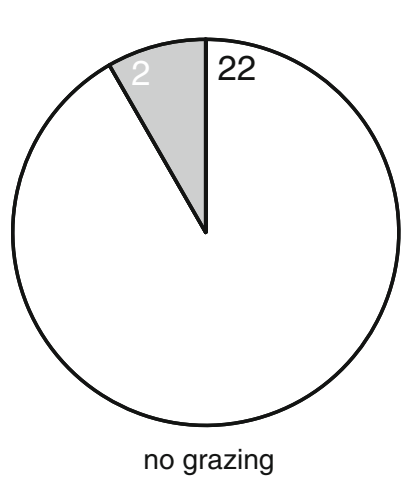

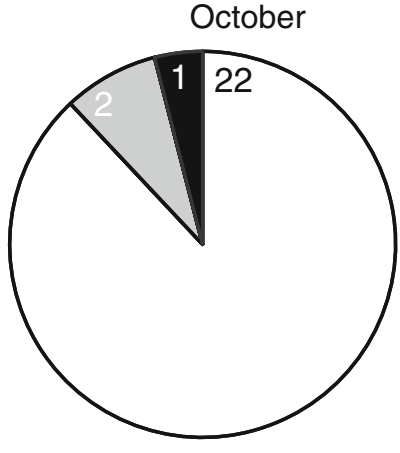

low intensity grazing

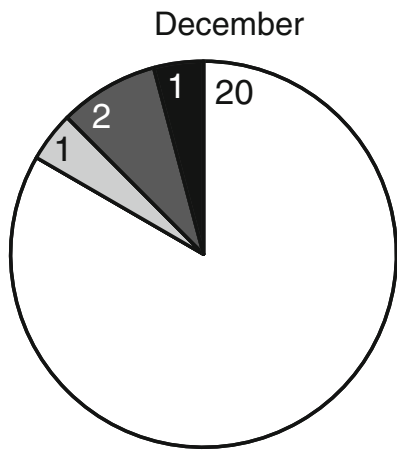

low intensity grazing

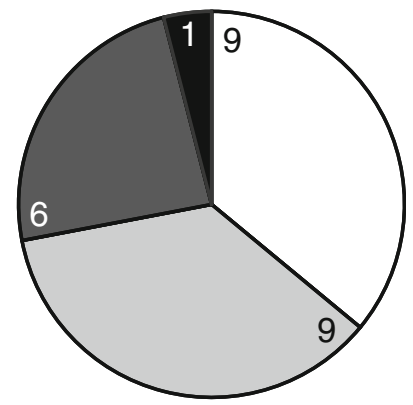

high intensity grazing

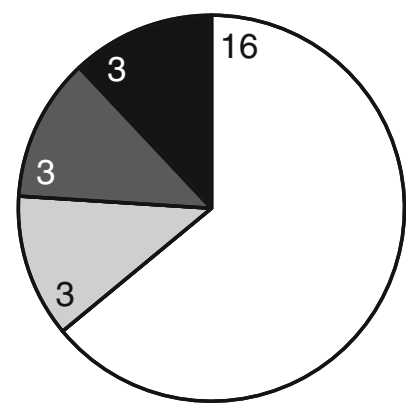

high intensity grazing

Fig. 2 Distribution of undamaged (white), lightly damaged (light grey), heavily damaged (dark grey) and missing (black) nests per grazing treatment after the first (October) and second (December) grazing rounds 


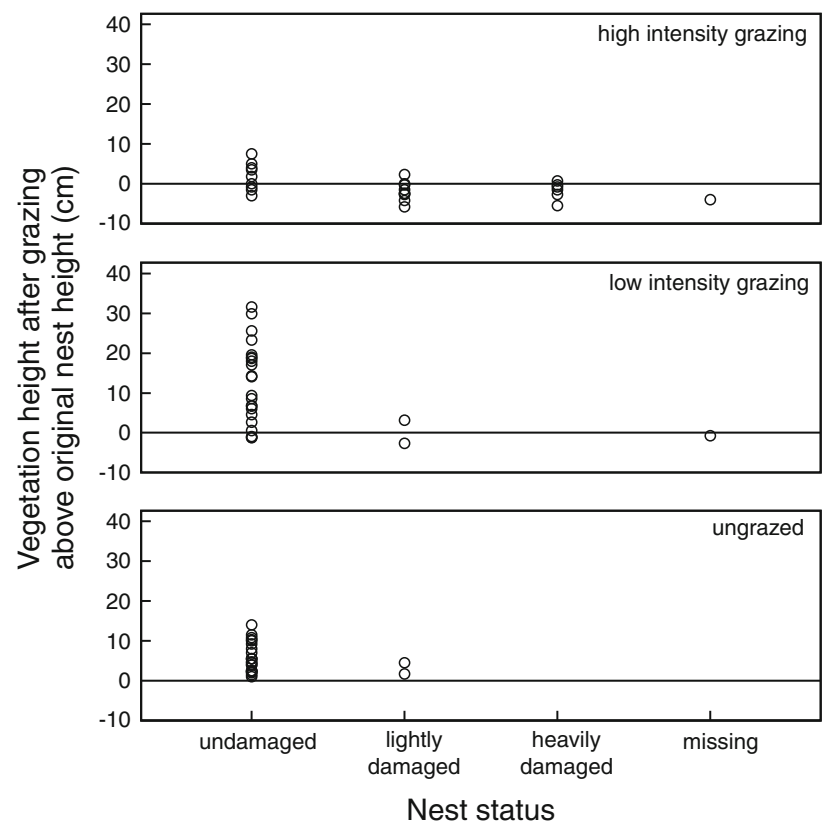

Fig. 3 Vegetation height after the first grazing round (October) relative to the nest height prior to grazing, per nest status and grazing treatment

caterpillar density (number of caterpillars per nest volume) between the two study sites $\left(t\right.$ test, $\mathrm{T}_{23}=-0.69$, $p=0.50$ ). This confirmed our assumption that nest volume could be used as a proxy for the number of caterpillars per nest.

\section{Nest volume}

Prior to grazing, the nests at Thier de Lanaye (low intensity grazing treatment: mean nest size $14.0 \mathrm{~cm}^{3} \pm 1.4 \mathrm{SE}$ ) were significantly smaller $\left(t\right.$ test, $\mathrm{T}_{72}=12.4, p<0.001$, critical $p=0.017$ ) than at Bemelerberg (ungrazed treatment: mean nest size $59.6 \mathrm{~cm}^{3} \pm 5.9 \mathrm{SE}$, heavily grazed treatment: mean nest size $\left.59.9 \mathrm{~cm}^{3} \pm 5.9 \mathrm{SE}\right)$. At Bemelerberg, nest volume did not differ prior to grazing between the ungrazed and high intensity grazing treatment ( $t$ test, $\left.\mathrm{T}_{47}=-0.03, p=0.98\right)$. During both grazing rounds nest volume declined strongly in all treatments $(t$ test, after first grazing round $\mathrm{T}_{73}=-18.7, p<0.001$, after second grazing round $\left.\mathrm{T}_{73}=-10.0, p<0.001\right)$. The relative decline in nest size during the first grazing round was stronger in the high intensity grazing treatment $(81 \%)$ than in the ungrazed $(61 \%)$ and low intensity grazing treatment $(60 \%)$ (Table 3). Overall, nests that appeared damaged after the first grazing round decreased significantly more in size than undamaged nests (Fig. 5, Mann-Whitney, $\mathrm{U}=248, \mathrm{Z}=-3.7, p<0.001)$. During the second grazing round the decline in nest size did not differ between treatments.

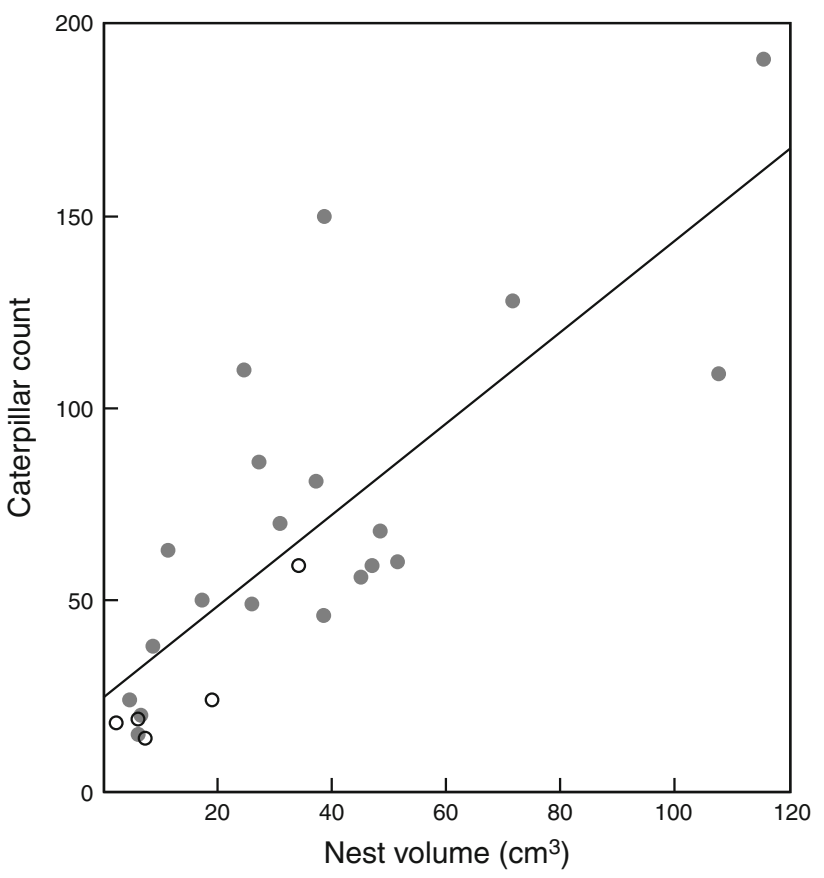

Fig. 4 Relationship between nest volume and the number of caterpillars per nest in August $\left(r^{2}=0.62\right)$ at Bemelerberg (high intensity grazing and no grazing treatment, represented by solid circles) and Thier de Lanaye (low intensity grazing, represented by open circles)

Spring caterpillar counts

As the nest size prior to grazing was significantly lower at Thier de Lanaye, absolute caterpillar counts in spring could not be used to asses the effects of grazing on caterpillar survival. Instead, we used the number of caterpillars per nest in early spring, relative to the nest size prior to grazing. This relative caterpillar count differed strongly between treatments (ANOVA $\mathrm{F}_{2}, 71=10.8, p<0.001$ ) with $50 \%$ lower caterpillar survival rates at the high intensity grazing treatment compared to both the ungrazed and the low intensity grazing treatment (Fig. 6). Nests that appeared damaged after the first grazing round had

Table 3 ANOVA results testing for differences between the grazing treatments with respect to change in nest volume after the first and second grazing round

\begin{tabular}{lllr}
\hline & $F$ & $d f$ & \multicolumn{1}{l}{$p$} \\
\hline After first grazing round (October) & 11.026 & 2,71 & $<0.001$ \\
No grazing-Low intensity & & & 0.987 \\
No grazing-High intensity & & & $<0.001$ \\
Low intensity-High intensity & & & $<0.001$ \\
After second grazing round (December) & 1.057 & 2,71 & 0.353 \\
No grazing-Low intensity & & & 0.998 \\
No grazing-High intensity & & & 0.445 \\
Low intensity-High intensity & & & 0.405 \\
\hline
\end{tabular}




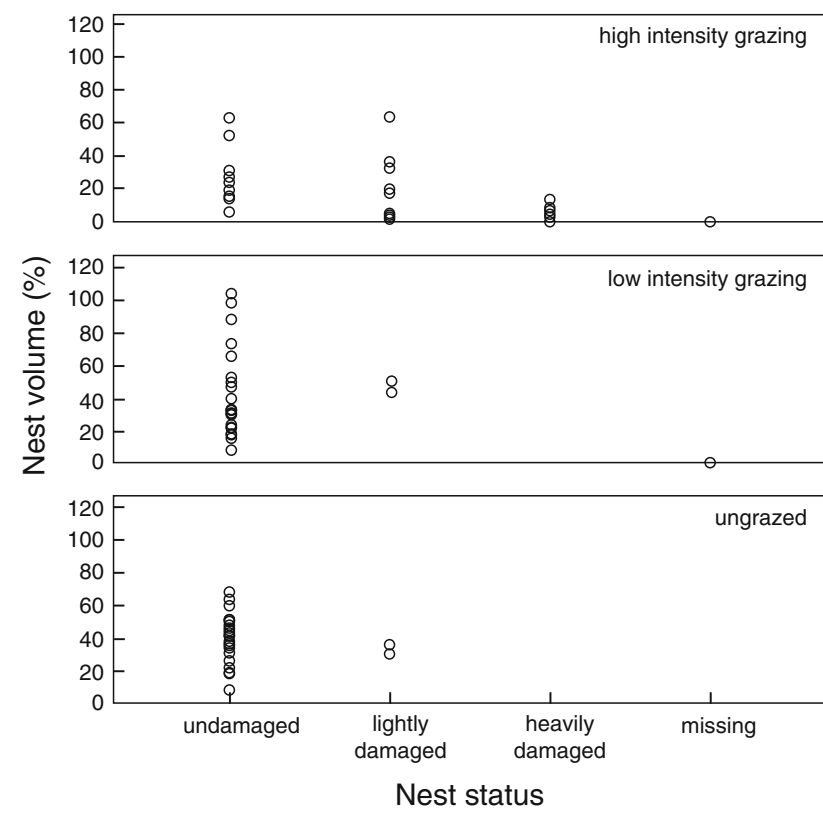

Fig. 5 Nest volume after the first grazing round (October) as a percentage of the nest volume prior to grazing in relation to nest status

significantly lower caterpillar survival rates than undamaged nests (Mann-Whitney, $U=241, \quad \mathrm{Z}=-3.8$, $p<0.001)$.

\section{Discussion}

Grazing is an essential management tool for the conservation of species-rich semi-natural grasslands (Baldock et al. 1996; Ostermann 1998; Willems 2001). However, grazing can also have severe negative effects on the very species the grazing management aims to conserve (Schtickzelle et al. 2007; Konvicka et al. 2008). In this study we show that intensive sheep grazing can cause substantial damage to nests of hibernating $M$. cinxia caterpillars. Survival in the high intensity grazing treatment was about $50 \%$ lower than in the ungrazed treatment. We also provide evidence that grazing intensity can be an important factor determining the extent to which caterpillar nests are negatively affected by sheep grazing.

\section{Effects of high intensity grazing}

The decreased caterpillar survival rate in the high intensity grazing treatment was predominantly caused by a decrease in the number of surviving caterpillars per nest, rather than disappearance of whole nests. Nest survival was only slightly lower in the high intensity grazing treatment (88\%), compared to the ungrazed control treatment $(100 \%)$. Overall, nest survival in this experiment was

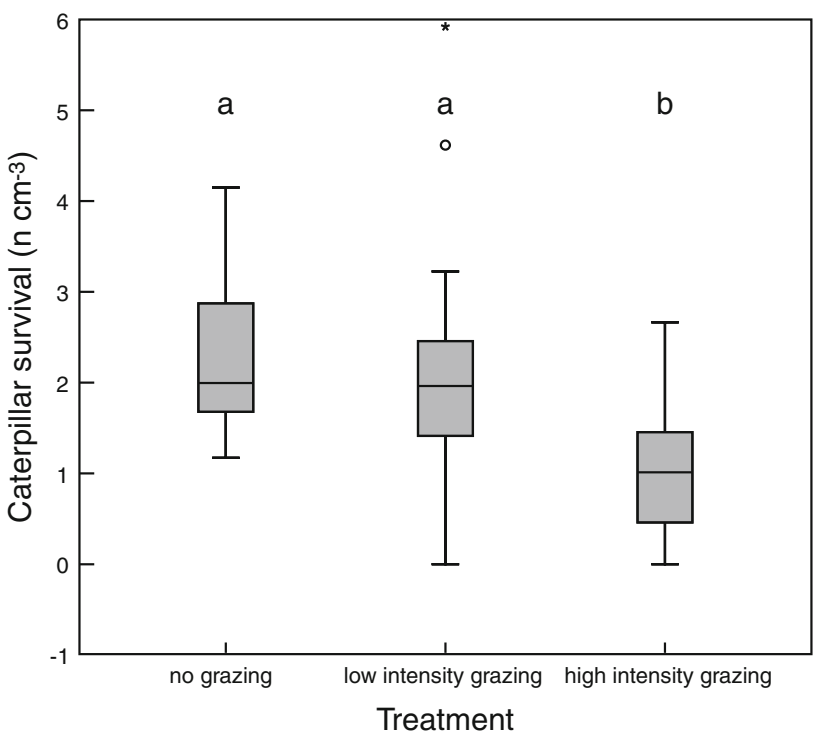

Fig. 6 Caterpillar survival per treatment measured as the number of caterpillars in March relative to the nest volume prior to grazing (September). Different letters represent differences between treatments (significant at the 0.01 level). Symbols depict outliers $\left(^{\circ}\right)$ and extremes $(*)$

extremely high, with nest survival rates in all treatments well above the $80 \%$ average overwinter nest survival reported for this species (Kuussaari 1998). In spite of the high nest survival rates, caterpillar survival was halved in the high intensity grazing treatment compared to the ungrazed control treatment. The number of caterpillars surviving per nest was especially low in nests that were heavily damaged. Some of the damaged nests $(20 \%)$ were on the ground and looked flattened, suggesting that they were trampled. Most damaged nests however, were still suspended in the vegetation. The stronger reduction in vegetation height at damaged nest sites compared to undamaged nest locations, suggests that most nest damage was caused by sheep during grazing. Most likely the sheep ingested (partial) nests, tearing the silk and sometimes causing remaining caterpillars to fall out of the nest. This was confirmed by the fact that the vegetation height at damaged nest sites had on average been reduced to below the height where the nest had been prior to grazing. This means that the vegetation to which damaged nests were attached was in most cases eaten by the sheep, making it likely that the sheep ingested (partial) nests with this vegetation. In contrast, at undamaged nest sites the vegetation height after grazing was on average still higher than the nest height prior to grazing. Such ingestion of insects by grazers is known as incidental omnivory (Bonal and Munoz 2007; Gómez and Gómez-Megías 2002; Polis et al. 1989). For butterflies our study seems to be the first direct proof of such incidental omnivory, although it has 
previously been suggested to be a major cause of butterfly declines at grazed sites (Baines et al. 1994).

Interactions with habitat characteristics

In the low intensity grazing treatment, the impact of grazing on nest size and caterpillar survival was much lower than in the high intensity grazing treatment (no significant difference compared to no grazing). Nonetheless, the type of damage to caterpillar nests (trampling versus ingestion and the reduction in nest size per nest damage category) was similar at both study sites. This was unaffected by some apparent differences between the two sites, like the average nest size prior to grazing, which was about four times larger at the high intensity grazing site. This indicates that the extent of damage to caterpillar nests, rather than the type of damage caused by grazing, varies under different grazing intensities.

Grazing intensity, habitat characteristics and herbivore behaviour are all likely to be major factors determining grazing impact on larval mortality. This is illustrated in our study by the absence of clear grazing effects (both on the vegetation and on caterpillar nests) after the second grazing round in the high intensity grazing treatment. This grazing round was conducted over a longer period and at much lower stocking densities than the first grazing round. Numerical grazing intensity (sheep $\times$ days $\times \mathrm{ha}^{-1}$ ) was higher than during the first grazing round in the low intensity grazing treatment, but apparently the experienced grazing pressure (i.e. the proportion of vegetation removed close to caterpillar nests) and hence actual nest damage were much lower. Also, nest survival rates in both grazed treatments in this study were considerably higher than the survival rates measured during a pilot study in 2007. In this pilot, conducted at the same sites and with the same experimental set-up, only two out of seven nests (30\%) survived in the high intensity grazing treatment, compared to five out of seven $(70 \%)$ in the low intensity grazing treatment and seven out of seven $(100 \%)$ in the ungrazed control (C.G.E. van Noordwijk, unpublished data). It thus appears that the effect of grazing on nest survival may vary substantially between years, as was previously reported for incidental omnivory on phytophagous beetles (Bonal and Munoz 2007; Gómez and Gómez-Megías 2002). This variation may be due to the fact that the proportion of removed vegetation does not only depend on grazer density, but also on the amount and quality of food available to the grazers (Prache et al. 1998; Roguet et al. 1998). Food availability may vary substantially between years, depending on weather conditions (driving biomass production) and availability of alternative food sources. Grazing impact is also likely to show spatial variation within the site (Prache et al. 1998). In addition, weather conditions in the period preceding or following management may also alter the effects of grazing, through shifts in the importance of food or shelter availability for insects. This has been reported as a cause of major variation in insect mortality caused by mowing (Humbert et al. 2009). More elaborate replicated studies are highly needed to establish more exactly how grazing intensity influences larval survival and how this interacts with habitat characteristics and grazing behaviour.

\section{Species-specific traits affecting vulnerability to grazing}

It is increasingly acknowledged that the extent to which different species are affected by particular disturbances can be predicted from their traits (Berg et al. 2010; van Kleef et al. 2006; van Noordwijk et al. 2012; van Turnhout et al. 2010; Vandewalle et al. 2010). There are a number of traits that determine the vulnerability of invertebrate species to grazing management and especially incidental omnivory. First, sedentary species are more severely affected than mobile arthropods. Mobile species may be able to evade grazers by flying or walking away (Berggren 2004) or simply dropping to the ground (Gish et al. 2011). In contrast, species living within plant structures will be unable to evade grazers (Gómez and Gómez-Megías 2007) as will inactive insects (e.g. hibernating) and insects living within closed cocoons or silk nests. Also mobile species can only evade grazers if they can detect them in time (Gish et al. 2010, 2011).

A third trait affecting species' vulnerability to grazing management is their location within the vegetation, especially during immobile life stages. Many grazers, including sheep, graze selectively (Parsons and Dumont 2003; Roguet et al. 1998), favouring highly palatable items like flowers, buds and forbs over food items with low nutritional value, like tall grasses. Invertebrates associated with the favoured vegetation structures are therefore likely to be more affected by grazing management, even at relatively low grazing intensities. In addition, invertebrates living higher in the vegetation column will have a higher risk of incidental omnivory than species living close to the ground (Zamora and Gómez 1993).

Body size- is another life-history trait that possibly affects a species' risk to incidental omnivory. Mowing has been demonstrated to be more detrimental to large-bodied species than to small species (Humbert et al. 2009, 2010). To what extent this also applies to mortality caused by grazing is unclear. In contrast to mowing, grazers may actively avoid insects depending on their ability to detect them. Large-bodied species will generally have a higher chance of being detected by the grazer than small species. On the other hand, just as with mowing, larger species, or structures such as caterpillar nests, have a higher chance of 
being encountered purely by chance. While individual species are likely to die even when only a part of them is ingested, this is not the case for clusters of individuals, like a caterpillar nest of $M$. cinxia. Our results confirm that for such gregarious species, damage to the nest due to incidental ingestion does not necessarily lead to mortality of the whole larval group. This reduces the negative effects of increased encounter rates of larger species and renders it likely that the effects we found are similar for caterpillars hibernating individually.

\section{Timing of grazing}

The identified traits determining a species' vulnerability to incidental omnivory vary throughout the life-cycle of most invertebrate species, including butterflies. This means that the impact of grazing management strongly depends on the timing of this management in relation to the phenology of the species. Most butterflies living in temperate grasslands are inactive during the winter months, often hibernating as immature stages. Previous studies have often recommended to confine grazing and mowing management to this inactive winter season (Ellis 2003; Oates 1995; Schtickzelle et al. 2007) to minimise negative effects on food and oviposition site availability. However, our results show that this advice may have serious consequences for larval survival. In Dutch calcareous grasslands, where introduction of autumn grazing around 1980, led to improved habitat conditions for most calcareous grassland butterflies (Smits 2010), these species did not recover. Remaining populations of Erynnis tages and Aricia agestis even continued to decline and other species, which had already disappeared, did not return (WallisDeVries et al. 2002). All these species hibernate as inactive caterpillars or pupae in the vegetation or litter layer of nutrient-poor grasslands (Bink 1992). Our results suggest that the management aimed at the conservation of these threatened species and restoration of their habitat may have had adverse consequences. Similarly, Smee et al. (2011) have demonstrated that the occurrence of the endangered Euphydryas aurinia (Annex II species of the European Habitats Directive) in the UK was especially determined by high sward heights in autumn, in addition to food plant availability and intermediate stocking density. The lifecycle of E. aurinia closely resembles that of $M$. cinxia, which renders it very likely that incidental ingestion is also a large threat for this highly endangered butterfly species. Based on our results, we thus strongly oppose the advice to confine grazing and mowing management to the inactive winter season. In general we expect that mortality rates will be much lower when management is conducted while species are active (not hibernating). Also, adult life-stages are generally more mobile and less demanding with respect to their habitat requirements than immature stages (Bourn and Thomas 2002; Fartmann and Hermann 2006), making them less vulnerable to negative effects of management practises.

Implications for conservation management

This study illustrates the need to strike the balance between positive and negative effects of management measures, in order to integrate the requirements of different organisms (WallisDeVries et al. 2002) and life-stages in semi-natural grassland conservation. Balancing positive and negative effects of management for a large range of species, including plants and animals, is not an easy task. Management in semi-natural grasslands should be intensive enough to reduce nutrient availability (Willems 2001) and to create a heterogeneous vegetation structure with favourable microclimatic conditions for plants (Bobbink and Willems 1993) and invertebrates (Morris 2000; Morris et al. 1990; Poyry et al. 2004). At the same time disturbance should be kept to a minimum. This delicate balance is compromised even more as intensive management is currently needed to overcome the encroachment of coarse grasses and shrubs due to abandonment (EEA 2004; Laiolo et al. 2004), increased nitrogen deposition (Bobbink and Hettelingh 2011; Bobbink et al. 1998) and climate change (WallisDeVries and van Swaay 2006). At the same time land-use change has caused increased habitat fragmentation, which negatively affects the ability of populations to recover from local disturbances (Hodgson et al. 2005; Kruess and Tscharntke 1994). To minimise damage to endangered insect populations the management regime should be tailor-made to suit the needs of locally occurring species, while being adapted to the local vegetation productivity. Effects of management measures on species can be predicted from their traits (life-history and behavioural). Incorporating species traits in the design of habitat management plans thus appears a prerequisite for success, but this approach has not yet been widely applied (van Noordwijk et al. 2012; Verberk et al. 2008). Our results demonstrate both the need to start incorporating these traits in conservation policy and practice as well as the necessity to pay more attention to inactive and immature life-stages. In particular, agri-environment schemes for semi-natural grasslands and conservation action plans for endangered butterflies, such as the European habitats directive species Euphydryas aurinia, should incorporate the effects of high intensity autumn grazing on hibernating caterpillars.

Acknowledgments We thank Stichting het Limburgs Landschap and Ville de Visé for their kind permission to conduct research on their premises and for their help with the experimental set-up. We are very grateful to Jan Kuper, Remco Versluijs, Theo Peeters, Albert Dees, Marleen Gramberg and Rob Raedts for their help in the field. 
We also thank the shepherds Evert van Acker and Peer de Win for their kind assistance. We thank two anonymous reviewers for their constructive comments on an earlier version of this article. This research received financial support from the Dutch Ministry of Economy, Agriculture and Innovation as part of the calcareous grassland project within the development and management of nature quality program $(\mathrm{O}+\mathrm{BN})$.

Open Access This article is distributed under the terms of the Creative Commons Attribution License which permits any use, distribution, and reproduction in any medium, provided the original author(s) and the source are credited.

\section{References}

Aviron S, Herzog F, Klaus I, Schüpbach B, Jeanneret P (2010) Effects of wildflower strip quality, quantity, and connectivity on butterfly diversity in a Swiss arable landscape. Rest Ecol 19(4):500-508

Baines D, Sage RB, Baines MM (1994) The implications of red deer grazing to ground vegetation and invertebrate communities of Scottish native pinewoods. J Appl Ecol 31(4):776-783

Baldock D, Beaufoy G, Brouwer F, Godeschalk F (1996) Farming at the margins: abandonment or redeployment of agricultural land in europe. IEEP, London \& IBN-DLO, The Hague

Berg MP, Kiers ET, Driessen G, van der Heijden M, Kooi BW, Kuenen F, Liefting M, Verhoef HA, Ellers J (2010) Adapt or disperse: understanding species persistence in a changing world. Glob Change Biol 16(2):587-598

Berggren Ã (2004) Impact of grazing on individual male movement in Roesel's bush-cricket Metrioptera roeseli: one possible clue to species range expansion. J Insect Behav 17(4):419-429

Bink FA (1992) Ecologische atlas van de dagvlinders van NoordwestEuropa. Schuyt \& Co, Haarlem

Bobbink R, Hettelingh JP (2011) Review and revision of empirical critical loads and dose-response relationships. Proceedings of an expert workshop. Noordwijkerhout, 23-25 June 2010

Bobbink R, Willems JH (1993) Restoration management of abandoned chalk grassland in the Netherlands. Biodivers Conserv 2(6):616-626

Bobbink R, Hornung M, Roelofs JGM (1998) The effects of air-borne nitrogen pollutants on species diversity in natural and seminatural European vegetation. J Ecol 86(5):717-738

Bonal R, Munoz A (2007) Multi-trophic effects of ungulate intraguild predation on acorn weevils. Oecologia 152(3):533-540

Bourn NAD, Thomas JA (2002) The challenge of conserving grassland insects at the margins of their range in Europe. Biol Conserv 104(3):285-292

Carvell C (2002) Habitat use and conservation of bumblebees (Bombus spp.) under different grassland management regimes. Biol Conserv 103(1):33-49

Dennis P, Young MR, Gordon IJ (1998) Distribution and abundance of small insects and arachnids in relation to structural heterogeneity of grazed, indigenous grasslands. Ecol Entomol 23(3):253-264

Dover J, Spencer S, Collins S, Hadjigeorgiou I, Rescia A (2011) Grassland butterflies and low intensity farming in Europe. J Insect Conserv 15:129-137

EEA (2004) High nature value farmland: characteristics, trends and policy challenges. EEA Report No1/2004, European Environmental Agency, Copenhagen, Denmark

Ellis S (2003) Habitat quality and management for the northern brown argus butterfly Aricia artaxerxes (Lepidoptera: Lycaenidae) in North East England. Biol Conserv 113(2):285-294
Fartmann T, Hermann G (2006) Larvalökologie von Tagfaltern und Widderchen in Mitteleuropa. Landschaftsverband WestfalenLippe, Münster

Franzén M, Ranius T (2004) Occurrence patterns of butterflies (Rhopalocera) in semi-natural pastures in southeastern Sweden. J Nat Conserv 12:121-135

Gish M, Dafni A, Inbar M (2010) Mammalian herbivore breath alerts aphids to flee host plant. Curr Biol 20(15):628-629

Gish M, Dafni A, Inbar M (2011) Avoiding incidental predation by mammalian herbivores: accurate detection and efficient response in aphids. Naturwissenschaften 98(9):731-738

Goffart P, Baguette M, Dufrêne M, Mousson L, Nève G, Sawchik J, Wesierbs A, Lebrun P (2001) Gestion des milieux semi-naturels et restauration de populations menacées de papillons de jour. vol Travaux no. 25. Ministère de la Région Wallone, Direction générale des Resources naturelles et de l'environment, Division de la Nature et des Forêts, Jambes

Gómez JM, González-Megías A (2002) Asymmetrical interactions between ungulates and phytophagous insects: being different matters. Ecology 83(1):203-211

Gómez JM, Gómez-Megías (2007) Long-term effects of ungulates on phytophagous insects. Ecol Entomol 32(2):229-234

Greenhouse SW, Geisser S (1959) On methods in the analysis of profile data. Psychometrika 24(2):95-112

Hanski I (1999) Metapopulation ecology. Oxford series in Ecology and Evolution. Oxford University Press, Oxford

Hodgson JG, Grime JP, Wilson PJ, Thompson K, Band SR (2005) The impacts of agricultural change (1963-2003) on the grassland flora of Central England: processes and prospects. Basic Appl Ecol 6(2):107-118

Humbert JY, Ghazoul J, Walter T (2009) Meadow harvesting techniques and their impacts on field fauna. Agric Ecosyst Environ 130(1-2):1-8

Humbert JY, Ghazoul J, Richner N, Walter T (2010) Hay harvesting causes high orthopteran mortality. Agric Ecosyst Environ 139(4):522-527

Konvicka M, Benes J, Cizek O, Kopecek F, Konvicka O, Vitaz L (2008) How too much care kills species: Grassland reserves, agri-environmental schemes and extinction of Colias myrmidone (Lepidoptera: Pieridae) from its former stronghold. J Insect Conserv 12:519-525

Kruess A, Tscharntke T (1994) Habitat fragmentation, species loss, and biological-control. Science 264(5165):1581-1584

Kruess A, Tscharntke T (2002a) Contrasting responses of plant and insect diversity to variation in grazing intensity. Biol Conserv 106(3):293-302

Kruess A, Tscharntke T (2002b) Grazing intensity and the diversity of grasshoppers, butterflies, and trap-nesting bees and wasps. Conserv Biol 16(6):1570-1580

Kuussaari M (1998) Biology of the Glanville fritillary butterfly (Melitaea cinxia). PhD thesis, Helsinki University

Laiolo P, Dondero F, Ciliento E, Rolando A (2004) Consequences of pastoral abandonment for the structure and diversity of the alpine fauna. J Appl Ecol 41:294-304

Morris MG (1973) The effects of seasonal grazing on the Heteroptera and Auchenoryncha (Hemiptera) of chalk grasslands. J Appl Ecol 10:20

Morris MG (2000) The effects of structure and its dynamics on the ecology and conservation of arthropods in British grasslands. Biol Conserv 95(2):129-142

Morris MG, Hillier SH, Walton DWH, Wells DA (1990) The effects of management on the invertebrate community of calcareous grasslands. In: Hillier SHH, Walton DWH, Wells DA (eds) Calcareous grasslands: ecology and management. Bluntisham Books, Huntingdon, pp 128-133 
Mortimer SR, Hollier JA, Brown VK (1998) Interactions between plant and insect diversity in the restoration of lowland calcareous grasslands in southern Britain. Appl Veg Sci 1(1):101-114

Oates MR (1995) Butterfly conservation within the management of grassland habitats. In: Pullin AS (ed) Ecology and conservation of butterflies. Chapman and Hall, London, pp 98-112

Oertli S, Muller A, Steiner D, Breitenstein A, Dorn S (2005) Crosstaxon congruence of species diversity and community similarity among three insect taxa in a mosaic landscape. Biol Conserv 126(2):195-205

Ostermann OP (1998) The need for management of nature conservation sites designated under Natura 2000. J Appl Ecol 35(6): 968-973

Parsons AJ, Dumont B (2003) Spatial heterogeneity and grazing processes. Anim Res 52(2):161-179

Polis GA, Myers CA, Holt RD (1989) The ecology and evolution of intraguild predation-potential competitors that eat each other. Annu Rev Ecol Syst 20:297-330

Poschlod P, WallisDeVries MF (2002) The historical and socioeconomic perspective of calcareous grasslands-lessons from the distant and recent past. Biol Conserv 104(3):361-376

Poyry J, Lindgren S, Salminen J, Kuussaari M (2004) Restoration of butterfly and moth communities in semi-natural grasslands by cattle grazing. Ecol Appl 14(6):1656-1670

Poyry J, Luoto M, Paukkunen J, Pykala J, Raatikainen K, Kuussaari M (2006) Different responses of plants and herbivore insects to a gradient of vegetation height: an indicator of the vertebrate grazing intensity and successional age. Oikos 115(3):401-412

Prache S, Gordon IJ, Rook AJ (1998) Foraging behaviour and diet selection in domestic herbivores. Annales De Zootechnie 47(5-6): 335-345

Pywell RF, Meek WR, Hulmes L, Hulmes S, James KL, Nowakowski M, Carvell C (2011) Management to enhance pollen and nectar resources for bumblebees and butterflies within intensively farmed landscapes. J Insect Conserv 15(6):853-864

Roguet C, Dumont B, Prache S (1998) Selection and use of feeding sites and feeding stations by herbivores: a review. Anim Res 47(4):225-244

Samways MJ (1994) Insect conservation biology. Chapman and Hall, London

Schtickzelle N, Turlure C, Baguette M (2007) Grazing management impacts on the viability of the threatened bog fritillary butterfly Proclossiana eunomia. Biol Conserv 136(4):651-660

Siepel H (1995) Applications of microarthropod life-history tactics in nature management and ecotoxicology. Biol Fertil Soils 19(1):75-83

Smee M, Smyth W, Tunmore M, ffrench-Constant R, Hodgson D (2011) Butterflies on the brink: habitat requirements for declining populations of the marsh fritillary (Euphydryas aurinia) in SW England. J Insect Conserv 15:153-163

Smits NAC (2010) Restoration of nutrient-poor grasslands in Southern Limburg. PhD Thesis, Utrecht University

Stevens CJ, Dise NB, Mountford JO, Gowing DJ (2004) Impact of nitrogen deposition on the species richness of grasslands. Science 303(5665):1876-1879
Thomas JA, Simcox DJ, Hovestadt T (2011) Evidence based conservation of butterflies. J Insect Conserv 15:241-258

van Kleef HH, Verberk WCEP, Leuven RSEW, Esselink H, van der Velde G, van Duinen GA (2006) Biological traits successfully predict the effects of restoration management on macroinvertebrates in shallow softwater lakes. Hydrobiologia 565:201-216

van Noordwijk CGE, Boer P, Mabelis AA, Verberk WCEP, Siepel H (2012) Life-history strategies as a tool to identify conservation constraints: a case-study on ants in chalk grasslands. Ecol Ind 13:303-313

van Swaay CAM, Cuttelod A, Collins S, Maes D, Munguira ML, Sasic M, Settele J, Verovnik R, Verstrael T, Warren MS, Wiemers M, Wynhoff I (2010) European red list of butterflies. Publications Office of the European Union, Luxembourg

van Turnhout CAM, Foppen RPB, Leuven RSEW, Van Strien A, Siepel H (2010) Life-history and ecological correlates of population change in Dutch breeding birds. Biol Conserv 143(1):173-181

Vandewalle M, de Bello F, Berg MP, Bolger T, Doledec S, Dubs F, Feld CK, Harrington R, Harrison PA, Lavorel S, da Silva PM, Moretti M, Niemela J, Santos P, Sattler T, Sousa JP, Sykes MT, Vanbergen AJ, Woodcock BA (2010) Functional traits as indicators of biodiversity response to land use changes across ecosystems and organisms. Biodivers Conserv 19(10):2921-2947

Verberk WCEP, Siepel H, Esselink H (2008) Applying life-history strategies for freshwater macroinvertebrates to lentic waters. Freshw Biol 53(9):1739-1753

Vessby K, Söderström B, Glimskär A, Svensson B (2002) Speciesrichness correlations of six different taxa in Swedish seminatural grasslands. Conserv Biol 16(2):430-439

WallisDeVries MF (2006) Larval habitat quality and its significance for the conservation of Melitaea cinxia in Northwestern Europe. In: Fartmann T, Hermann G (eds) Larvalökologie von Tagfaltern und Widderchen in Mitteleuropa, vol 3/4. Abhandlungen aus dem Westfalischen Museum fur Naturkunde, pp 281-294

WallisDeVries MF, van Swaay CAM (2006) Global warming and excess nitrogen may induce butterfly decline by microclimatic cooling. Glob Change Biol 12(9):1620-1626

WallisDeVries MF, Poschlod P, Willems JH (2002) Challenges for the conservation of calcareous grasslands in northwestern Europe: integrating the requirements of flora and fauna. Biol Conserv 104(3):265-273

WallisDeVries MF, Parkinson AE, Dulphy JP, Sayer M, Diana E (2007) Effects of livestock breed and grazing intensity on biodiversity and production in grazing systems. 4. Effects on animal diversity. Grass Forage Sci 62(2):185-197

Willems JH (2001) Problems, approaches, and, results in restoration of Dutch calcareous grassland during the last 30 years. Restor Ecol 9(2):147-154

Zamora R, Gómez JM (1993) Vertebrate herbivores as predators of insect herbivores - an asymmetrical interaction mediated by size differences. Oikos 66(2):223-228 